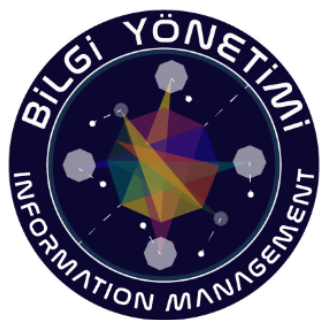

Bilgi Yönetimi

Dergisi

Cilt: 3 Sayı: 2 Yıl: 2020

https://dergipark.org.tr/tr/pub/by

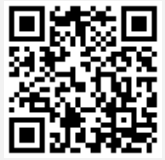

Hakemli Makaleler

Araştırma Makalesi

\section{Makale Bilgisi}

Gönderildiği tarih: 06.08. 2020

Kabul tarihi:

25.09. 2020

Yayınlanma tarihi: $\quad 31.12 .2020$

\section{Article Info}

Date submitted:

Date accepted:

06.08 .2020

Date published:

25.09. 2020

31.12. 2020

\section{Anahtar sözcükler}

Arşivcilik, Belge/Bilgi

Yönetimi, Dijital Dünya,

Paradigma Değişimi

Keywords

Archiving,

Records/Information

Management, Digital

World, Raradigm Shift

DOI numarasi

10.33721/by.777442

ORCID

0000-0002-0633-8307

\title{
Belge/Bilgi Yönetimi Disiplininde Olası Paradigma Değişiklikleri: Yeni Bir Rota Teklifi
}

\author{
Possible Paradigm Changes in Records/Information \\ Management Discipline: A New Route Proposal
}

\section{Mehmet TORUNLAR}

Cumhurbaşkanlığı Devlet Arşivleri Başkanlığı, mehmettorunlar06@gmail.com

$\ddot{O} \mathbf{z}$

İnsanın biyolojik yapısının yani beyinleşmesinin bir dış uzantısı olan arşivcilik ve belge/bilgi yönetimi mesleği yenidünya gerçeklikleri içerisinde kendisine farklı rotalar aramaya mecburdur. Elektronikleșen, dijitalleşen dünyada, mesleklerin geleceklerine ilişkin belirsizlikler ve kaygılar da mevcuttur. Arşivcilik ve belge/bilgi yönetimi mesleği açısından da bu yenidünya gerçekliğine karşı verilen tepkinin ne olacağı, mesleğin geleceğinin şekillenip değerliliğini ortaya koyacaktır.

Dijitalleşmenin çerçevelendirdiği bu yeni platformlarda mesleki olarak belirlenecek yeni rotalar, yeni iş, işlem, bilgi ve beceri setlerini devreye almayı zorunlu k1lıyor. Hayata geçirilecek yenilikler ve anlayışlar, mesleğin etkilenme gücünü belirleyeceği gibi, etkileme ve etkileşim gücünü de belirleyecek, gelecekte kendisine önemli ve değerli bir konuşlanma da getirecektir. Tüm bunların olması için ise mesleki formasyon açısından köklü paradigma (değerler dizini) değişikliğine ihtiyaç vardır. Makale mesleklerin önemi ve değeri üzerinden değil, fonksiyonları ve etkileşimleri açısından yeni değerler dizisine yönelinmesi önermesi çerçevesinde bir zihin egzersizi denemesidir.

\begin{abstract}
The profession of archiving and records/information management, which is an external extension of the biological structure of human beings, that is, is obliged to look for different routes in the new world realities. There are also uncertainties and concerns about the future of professions in the electronic, digitalized world. Archivalism, in terms of records/information management profession, will show how the future of the profession will be shaped and valued.

In these new platforms framed by digitalization, new routes to be determined professionally require new business, process, knowledge and skill sets to be put into operation. The innovations and understandings that will be implemented will determine the power of the profession to be influenced as well as the power of influencing and interacting, and will bring an important and valuable deployment to it in the future. For all this to happen, a radical paradigm change is needed in terms of professional formation. The article is a mental exercise experiment within the framework of the proposition to focus on a new set of values in terms of functions and interactions, not on the importance and value of professions.
\end{abstract}

\section{Giriş}

İnsanın maddi dünya ile yaptığı her türlü etkileşim insana bir şey katarken o etkileşimden elde edilenlerin geçmişte edinilenlerle birleştirilmesi yeni bir şeyi de ortaya koyar; bu devinim de sürekli gelişim olarak hayata yansır. 
İnsanların, geçmiş bilgilerini bugüne ve geleceğe aktarma becerisi, temelde hayatta kalma, çevreye uyum sağlama, gücü pekiştirip gelişimi sürekli hale getirme pratiğidir. Yani konunun biyolojik ve psikolojik boyutları da vardır.

İnsan, canlılar arasında en üst basamakta, dünyaya egemen olan bir varlık olarak tanımlansa da, biyolojik yapısıyla, doğuştan kendisinde var olan fiziksel özellikleriyle aslında son derece zayıf, savunmasız bir canlıdır. Dünyadaki diğer canlılara baktığınızda hepsinde insanlarda olmayan çok farklı ve güçlü yapısallıkların olduğunu görebilirsiniz. İnsanla bir karşılaştırma yaptığınızda ise insanın ne kadar kırılgan ve zayıf bir biyolojik varlık olduğunu anlarsınız. Bu noktada, BBC'nin 1999 yapımı 6 bölümlük Supernatural: The Unseen Powers of Animals ${ }^{1}$ belgesel serisini izlerseniz konuyla ilgili çok farklı örneklerle karşılaşabilirsiniz.

Ancak insanı diğer canlılar arasında öne çıkartıp, hâkim güç yapan bir özelliği vardır ki, o da zekasıdır. Bu zekâsı sayesinde öğrendiklerini, bildiklerini, tecrübelerini bugüne ve geleceğe taşıyarak, geçmişin birikiminin üzerine yeni bilgiler ekleyerek sürekli bir gelişim çizgisi oluşturabilmesidir. Tek başına son derece güçsüz olan insan, ancak zekasını kullanarak kendisinden katlarca güçlü, tehlikeli, yırtıcı canlılarla baş edebildi, hatta onların başına büyük bela oldu; öyle ki birçok canlının neslinin tükenmesine sebep teşkil etti. Bunu yaparken bazı temel dayanak noktaları vardı: Hayatta kalabilmek, neslini devam ettirmek ve egemen güç olmak.

İnsan, sürekli değişen, ne olacağı çok da önceden kestirilemeyen önce tabiat, sonra sosyal şartlar içerisinde hayatta kalabilmek; diğer canlılarda yaratılıştan/doğuştan var olan fiziki ve biyolojik güçlü özellikler karşısında, zayıflıklarını telafi etmek için zekâya dayalı bir sistem örgüsü oluşturarak denge kurmaktan öte hâkim güç haline gelmiştir.

Bunun kritik unsurlarından bir tanesi yukarıda da ifade ettiğimiz gibi, geçmiş-bugün-gelecek arasında birikim ve aktarım yapabilme kabiliyetidir. Üretilen bilgi, kazanılan deneyimler insanın hayatı ile sınırlı olmayıp yeni nesillere aktarılmalı; bunlar temel alınarak aktarılanlara yeni eklemeler yapılmalı ki gelişim sürekli olsun, güç devamlılık arz etsin. Tüm bilimsel gelişmeler geçmişte üretilmiş, bugün de var olan bilgi ve deneyim birikiminin üzerine inşa edilir. Üretilen yeni bir bilimsel gelişim ürününün aslında geçmişe dayalı bir kurulmuş iskeleti vardır. Bu iskelet üzerinden hareketle yeni incelemeler, deneyler, faaliyetler, çalışmalar yürütülür ve yeni bir bilgi/ürün ortaya çıkar. Bu yeni bilgi/ürün gelecekte ortaya çıkacak farklı bir bilimsel gelişmenin de iskeletidir aynı zamanda.

Fen alanı dışında sosyal gelişmeler, medeniyet oluşturmak da benzer bir güzergâhı takip eder. $\mathrm{Bu}$ alandaki ilerlemeler de geçmişte ürettiğimiz bilgi ve deneyimlerin üzerine eklenen birer tuğla katmanından başka bir şey değildir.

İşte insanın bilgiyi üretme, koruma ve geleceğe aktarma kabiliyetleri olmasaydı, her nesilde işe sıfırdan başlamak gerekecek veya bazı somut sınırlı bilgileri yeni kuşaklara aktarmakla yetinilecekti ki, bu da gelişim çizgisini dinamikleştirmek yerine aksine statik hale getirecekti. Her nesilde işe sıfır noktasından başlamak veya sınırlı bir hayatı devam ettirebilecek somut bilgi aktarımı yapmak güçlü özelliklere sahip diğer canlılar karşısında belki temel hayatta kalma pratiklerini uygulamaktan öteye gidemeyecek, büyük ihtimalle dünya üzerinde de bu kadar uzun süre varlığını sürdüremeyecekti. Oysa gelişim ve ilerleme yalnız somut şeyleri değil soyut şeyleri de kavrama ve aktarmakla ilgilidir. Öksüz'e $(2017$, s. 7) göre yüksek zekâ soyut kavramları anlayıp tartışan, düşük zekâ somutta takılıp kalan insanların işidir.

Soyutu kavrayamayan topluluklar somut ve basit çözümler arıyor ve Karl Popper'in dediği gibi 'Her karmaşık problemin basit bir çözümü var ve bu çözüm yanlış (aktaran: Öksüz, 2017, s. 7). İşte insanlık diğer canlılardan farklı olarak soyut şeyleri de kavrayıp geleceğe taşıyabilmenin yollarını bulduğu için başarılı bir varlık olarak fiziki, biyolojik güçsüzlüklerine rağmen dünyada var olmaya devam etmektedir. Diğer canlılara karşı egemen olma noktasında büyük bir koz olan, soyutu anlayıp somuta aktarma becerisi, bunu toplumsal özelliği haline getirenlerle getiremeyen toplumlar arasındaki gelişmişlik oranını da belirliyor.

Bunun için zekâsını kullanan insan, çevresinden aldığı bilgileri biriktirmiş, işlemiş, bunlara dair değerlendirmeler yapmış, bunları altyapı haline getirmiş, bir sonraki aşama için uygun gelişmeleri

\footnotetext{
${ }^{1}$ İlgili belgesele www.bbc.co.uk adresinden erişilebilir.
} 
sağlayacak, bir sonraki nesle aktaracak faaliyetler zinciri oluşturmuştur. İnsandan başka öğrendiklerini sınırlı da olsa yeni nesle aktarabilen canlılar da (filler gibi) zaten diğer canlılardan farklılıklarını ortaya koymaktadır.

Bilgi biriktirme, saklama, aktarma, ayrıştırma ve yeniden kullanma kabiliyeti insanı diğer canlılardan ayrıştıran en önemli özelliklerden birisi olarak karşımıza çıkmaktadır. Bugüne kadar bu özellikleriyle hayatta kalan insanın oluşturduğu dışsallıklar da onun biyolojik, psikolojik devamlılığına katkı sağlamaktadır.

Arşivcilik ve belge/bilgi yönetimi mesleği de bu çerçevede insanın hayatta kalmasına, psikolojik ve biyolojik devamlılığına önemli katkılarda bulunmuştur. Bugünden sonra da bu mesleğin belirleyeceği yeni rotalar, hem insanlığa hizmet edecek hem de mesleğin kendisine ve profesyonellerine katk1 sağlayacaktır. Makalede insanın biyolojik varlığının dışsal devamı olarak arşivcilik ve belge/bilgi yönetimi mesleğinin de hayatiyetine devam edebilmesi, hak ettiği gerçek konumu bulması açısından kendisine yeni rotalar belirleyerek bu çerçevede devreye alması gereken paradigma değişikliklerinden bahsedilmektedir.

\section{Her Araç İnsanın Bir Uzantısıdır; İnsan Beyinleşmesinin Uzantısı Arşivlerdir}

İnsanların, dünyada var olmalarıyla birlikte ortaya çıkan geçmiş bilgi, beceri ve deneyimlerini geleceği şekillendirecek kuşaklara aktarma özelliği, insanın fiziki ve biyolojik yapısının kapasitesini aşınca bu biyolojik yapının devamı veya uzantısı olarak dış dünyada oluşturduğu yapısallıklar içerisinde kendisini gösteriyor.

İnsanın bu dış yapısallığını, özelde matbaanın icadının getirdiği kişisel ve toplumsal değişimleri kendisine konu eden McLuhan (2014, s. 14), Edward T. Hall adlı bir antropologdan alıntıladığı görüşün konuyu anlamak adına, okuyucularına yardımcı olabileceğini belirtir: "Bugün insan, pratikte bedeniyle yapageldiği her şey için uzantılar geliştirmiştir. Silahların evrimi dişler ve yumrukla başlar, atom bombası ile biter. Giysiler ve evler, insanın biyolojik ısı denetim mekanizmalarının uzantısıdır. (....) Aslına bakılırsa, insan yapımı bütün maddi şeylere, insanın bir zamanlar bedeniyle ya da bedeninin ilgili parçasıyla yaptığı şeylerin uzantısı olarak bakmak mümkündür."

1960'lı yılların sonuna doğru "Araç Mesajdır” (The Medium is the Message) isimli kitabını yayımlayan McLuhan'a göre artık üretilen her araç, insanın bir uzantısıdır. Konuya biz de bu yaklaşım üzerinden bakarak devam edelim.

İnsanın milyonlarca y1l süren bilgi ve deneyimlerini yeni nesillere aktarma eylemi zamanla muazzam bir zihinsel, entelektüel veya bilgisel birikim oluşturdu. Bu, geçmişte yavaş seyrederken bile öyle bir büyüklüğe ve çeşitliliğe erişti ki, artık fiziki veya biyolojik sınırlarını aşan bu birikimi varlığının dışında bir takım araçlar ve yapılarla bedenin dışına taşıma ihtiyacı hissetti.

İnsanın fiziki, biyolojik varlı̆̆ının dışında zekâsının, beyninin, beyinlileşmesinin (ensefalizasyon) bir uzantısı olarak önce yazıyı icat etmesi, sonra matbaayı bulması, neticede insanın varlık olarak baş edemeyeceği çoklukta bilgi ürününün birikmesi sonucu, bilgileri kayıt altına alma ve bunları arşivleme teknikleri geliştirmesi, arşivler oluşturması, hayatta kalabilme, hayatını devam ettirebilme ve neslini koruma duygusunun bir yansımas1 olarak nitelenebilir. Yani hayata tutunmas1, kalıc1 olmas1 ve gelişmesi için insanın en temel pratiklerinden bir tanesinin, bilgi ve deneyimlerin yeni kuşaklara aktarımının beden varlığı dışında uygulamaya alınmasıdır.

İnsanın zekâsının dış yansıması olan arşivlere, hafiza ile de benzeştirilerek yaygın bir ifade ile hafiza mekânı* adı da verilmektedir. Nora'ya (2006, ss. 9-23) göre, hafıza mekânları bizzat varlıkları ve gerçeklik etkileriyle, hem hafızanın, hem ulusun içerdiği belirsizlikleri ve bunların doğurduğu karmaşık ilişkileri çabuk ve kesin çözüme bağlar ve hafızanın kendiliğinden olmadığı düşüncesinden doğarlar.

\footnotetext{
* Arşivlerin hafiza ile iliş̧kilendirilmesine katılmıyorum. Ancak arşivle ilgili çok yaygın bir analoji olduğu için alıntı olarak bunun üzerinden devam ettim. Bu konudaki görüsslerim Arşiv Dünyası Dergisi’nin 6. Cildinde "Arşiv-Hafiza-Kamusal Ensefalizasyon” başlı̆̆ ile yayımlanmıştır. Bkz. TORUNLAR, M . (2019). Arşiv-Hafiza-Kamusal Ensefalizasyon. Arşiv Dünyast, 6 (2), 100-133. Retrieved from https://dergipark.org.tr/tr/pub/ad/issue/51364/643206
} 
Eskiden ulusal bir tarih ve özel hafızalar varken bugün ulusal bir hafıza vardır; ancak bu hafızanın birliği sürekli bir katlanma ve tutarlılık arayışı içindeki bölünmüş ortak malvarlığı talebince sağlanmaktadır. Ortak mal varlığı da miras yoluyla edinilen mal anlamından çıkıp sizi oluşturan mal anlamına kavuşmuştur (Nora, 2017, s. 257). Yani beden dışında oluşturduğunuz bilgi, deneyim birikimi olan dışsal hafıza, artık içerdikleri ve tasavvur ettirdikleri aracılığıyla insanları, toplumları kimliklendirmekte, şekillendirmektedir.

Hafızanın (belleğin) kendisiyle ilgili olarak bugüne ilişkin deneyimimizin, büyük ölçüde geçmiş hakkındaki bilgiye dayandığını ifade eden Connerton (2019, s.9) da, günümüzün dünyasını, geçmişin olayları ve nesneleriyle nedensellik bağlantıları içerisinde bir bağlamda; yani geçmişin, o anda yaşamadığımız olayları ve o anda algılamadığımız nesneleri bağlamında yaşadığımız görüşünü dile getirir. Burada da yine geçmiş ile bugün arasında kurulan bir bağdan bahsedilmekte ve yine hafizaya (belleğe) gönderme yapılmaktadır.

$\mathrm{Bu}$ faaliyet alanını doğru, eksik, yanlış nasıl isimlendirirseniz isimlendirin, içeriğini ne şekilde doldurursanız doldurun, genel hatlarıyla işlevleri açısından geçmiş bilgilerin, deneyimlerin bugüne ve geleceğe taşınması, yeni nesillere bilgi ve deneyim aktarılması, bu noktada yeni bilgi üretilmesi faaliyetini yürütürsünüz. Onun bireysel, toplumsal hafizaya, kimliklendirmeye ve diğer alanlara yaptığ katkılar işin doğası olarak tali unsurlardır.

Varlık olarak insanın ürettiği her bilgi, bu bilgi ile kurulan tüm ilişkiler üzerinden inşa edilen gelecek, bu yapısallıkların (hem fiziki, biyolojik, psikolojik hem de beden dışı yapısallıklar) oluşum, gelişim ve kullanım biçiminden doğrudan etkilenir. Bu çerçevede insanın ürettiği bilgiyi, mümkün olan en iyi biçimde üretir, elde eder, tutar, saklar, ayrıştırır, sınıflar, tekraren kullanır, paylaşır ve üzerine yeni bilgiler eklersek gelecekte oluşmasını istediğimiz medeniyetin inşa süreci ile birlikte, nitelik ve içeriğini de belirlemeyi sağlayabiliriz.

Bilgimizi ve ciddi bir bilgi varlığı olan kamu varlığının, toplumun, devletin beyinlileşmesini (ensefalizasyonunu) yansıtan belge birikimimizi sistemli üretip, koruyup tekraren bunları başlangıç bilgisi olarak kullanmayı becerebilirsek yaşadığımız ve yaşayabileceğimiz birçok sorunu bertaraf edebileceğimiz gibi, öngöremediğimiz yeni sorunlar için de şimdiden hazırlıklı ve donanımlı olabiliriz.

Bu birikimin günümüzün teknolojisi ile hem hızlanması, hem de tahmin edilemez boyutta niceliksel olarak büyümesi, farklı önlemler alınmasının da gerekliliğini ortaya koyar.

Yani insanların artık fiziki, biyolojik gelişimi ve kapasitesi ile onu destekleyen klasik oluşumlar da yetersiz hale gelmiştir. Teknolojinin oluşturduğu yeni bilgi üretiminin, saklanmasının, dağıtımının, paylaşımının, erişiminin ve korunmasının içeriği ve kapasitesi, insanı doğal fiziki ve biyolojik ayarlarından çok daha ötelere itelemekte, bu noktada insanın her şarta uyum sağlama yeteneği bile ciddi sikıntılara girip sarsıntılar yaşayabilmektedir.

\section{Dijitalleşen Dünyanın Yeni Rotaları İçin Olası Değişiklikler}

İletişim teknolojisinin ve dijitalleşmenin getirdiği bugündeki yeni gerçeklikler, insanlığın belgeyle/bilgiyle olan geçmişini geleceğe taşıma faaliyeti, yine insanın çok uzun ama yavaş ilerlemesine aykırı gelişmeler olarak hızlanıp yaygınlaşarak, aslında bilinen paradigmaları değiştirerek ilerliyor. Toplumsal hatta bireysel değişimden çok öteye geçen, her alanda devletten, insan vücudu ve zihnine kadar sınırsızlaşan dijital teknolojiye dayalı bu yeni paradigma her şeyi tarttığımız-ölçtüğümüz ölçekleri, cetvelleri de değiştiriyor.

Böylesi köklü ve derinden etkili bir dönüşüm ve değişim çağında, akla sığmaz bilgi üretimi, paylaşımı içerisinden niteliklileri ayırt etme, bilgi ve deneyim birikimlerimizi gelecek nesillere sağlıklı, doğru ve düzgün şekilde aktarma başarısını yakalamamız gerekiyor.

Belge/bilgi yönetimi veya arşivcilik de bu paradigma değişiminden nasibini alacaktır. Buna itiraz etmek de meseleye çözüm getiremez. McLuhan (2014, s. 223), henüz elektronikleşmenin, dijitalleşmenin ortada olmadığı 1962 yılında, matbaanın insanı kabile insanı olmaktan çıkardığını, matbaanın bireyciliğin teknolojisi olduğunu ifade ederken insanların bu görsel teknolojiyi bir gün bir elektronik teknolojisiyle değiştirmeye karar verdiklerinde bireyciliğin de değişeceği görüşündedir. Bunun 
hakkında ahlaki bir yakınmada bulunmayı ise, parmakları budayan bir elektrikli testereye sövmeye benzetir. Mcluhan'ın öngörüsü bugün ete kemiğe bürünmüş biçimde hayatımıza dâhil olmuştur. Belge/bilgi yönetimi disiplininin artık klasik bir içerikle hayatına devam etmesi mümkün görünmemektedir. Bu devam ettiği takdirde başka disiplinler ortaya çıkan boşluğu doldurarak, bu disiplinden rol kapacaklardır.

Yine McLuhan'a (2014, s. 379) göre, bir toplum, özgül bir sabit duyu oranı ile kuşatıldığı zaman, bir başka durumu hayal etmesi artık çok güçtür. Yani değişim veya paradigma değişikliği engellenemeyecek doğal bir süreçtir.

Dijitalleşen dünyada değişim, insan beyni ve zekâsı ve onun dışsal uzantısı olan bu disiplinin geçmişte üretilmiş, bugünde var olan bilgi ve deneyim birikiminin üzerine inşa edilmektedir. Yani bu dijital dönüşümde temel iskelet, iletişim teknolojileri, ağlar, bilgiler ve bu bilgilerin arşivlenmesi, analiz edilmesi, değerlendirilmesi ve tekraren kullanılması üzerinden kendisine bir rota çizmiştir; bu rota üzerinden hareketine de devam etmektedir. Bunu ister donanım üzerinden ister yazılımlar, yapay zekâ, nesnelerin interneti vd. üzerinden inceleyin, temel iskeletin hep bilginin üretilmesi, saklanmas1, korunması, işlenmesi, sınıflanması, dağıtılması, paylaşılması, analiz edilmesi ve tekraren kullanılması üzerinden şekillendirilmeye çalışıldığını görürsünüz.

$\mathrm{Bu}$ şekillendirmenin ortaya çıkartacağı yeni uygulamalar, formlar etkileriyle geleceği, geçmiş tarım veya sanayi devriminin değişim ve dönüşümünden daha fazla etkileyecek gibi görünüyor. Bugün geçmişte kalan tarım ve sanayi devriminin etkilerini, dönüştürdüklerini ölçeklendirip ölçüp biçebiliyoruz. Ancak dijital gelişim ve dönüşümün ne olduğunu, hangi sınırlara kadar ilerleyebileceğini, nerede yeni bir yapısallığa iskelet oluşturacağını, geleceği, toplumları, insanları nasıl şekillendireceğini ölçümlemek, ölçüp biçip bir karara varmak bulunduğumuz noktada zor görünüyor. Bu gerçekliğe yönelik bir cetvelimizin de henüz olmadığı gerçeği, büyük bir sorun olarak karşımızda duruyor.

Dijitalleşmenin vardığı noktaya ve etkisine, ama temelde neyin dijitalleştiğine Canan ve Acungil (2018, ss. 69-70) uzay mekiği üzerinden güzel ve açıklayıcı bir örnek veriyorlar. Uzaya gönderilecek bir mekikte bir arıza olması durumunda kullanılacak yedek parçaların da mekiğe konulmasının ve taşınmasının zor ve çok masraflı olduğundan bahisle, uzaya yedek parçaların hammaddesinin ve ihtiyaç olduğunda onları yedek parça olarak basacak üç boyutlu yazıcıların gönderilmesinin yeterli olduğunu söylüyorlar. Buna göre yedek parçalar fiziksel bir yapı olsa da onun tasarımı ve şekli dijitalleştirilebilecek bilgidir.

Böylece çok daha az yükle, olası arızalara karşı gereken bilgileri arşivleyip yönetilir ve kullanılabilir kılarak silahlanmış olarak gönül rahatlığıyla uzaya açılabilirsiniz. Yani dijitalleşmenin, ürünleri, faaliyetleri, hizmetleri dijitale çevirmenin temelinde bilgi yer alıyor. Bu bilginin, hele ki dijital çağda yönetilebilir kılınmaması akla bile getirilemez.

Konumuz itibariyle dijital dönüşümün ne olduğu değil bu dönüşümün oturduğu temel iskelet bizi ilgilendirmektedir. Bu çerçevede meseleye yaklaştı̆̆ımızda, dijital dünyada bir birey olarak, toplum olarak, devlet olarak özgünlüğünüzle var olmak çok önemli bir sorundur. Benliğimizi, değerlerimizi, zenginliklerimizi, bilgi birikimimizi korumak ve gelecek nesillere aktarmak sorunun önemli bir parçasıdır, bu sorununun büyüklüğünü veya etkisini sağlıklı bir ölçeğe vurmak, ölçüp biçmek de şu anda imkânsız gibi görünüyor.

O halde ne yapmak gerekiyor? Bu sorunun tüm yönleriyle cevaplandırılması bizim ilgi ve beceri sınırını da, yeteneklerini de çok aşan bir husustur. Ancak bu dönüşümün temelinde olan alanla ilgili paradigma değişikliklerini tespit edip öneriler sunmak sorunun bir kısmının çözümüne aracılık edebilir. Bu makale dijital dönüşümün oturduğu iskelet olan belge/bilgi yönetiminde gerçekleşmesi gereken paradigma değişiklikleri sorunsalı üzerinde konumlanıyor.

\section{Paradigma Değişikliği}

Paradigma, bireyler ve toplum olarak, günlük hayatımızın bir parçası gibi görünen, sorgulamaksızın varlığına inandığımız, bu yüzden test etmeye bile gerek görmediğimiz, içinde yaşadığımız gerçeklik anlayışımızdır. Aslında, her şeyi birdenbire farklı görene kadar 
hakkında çok da düşünmediğimiz, içinde yaşayıp nefes aldığımız ve kültürümüzün bilinçdışı inanç sistemi gibidir paradigma.

Öncelikle paradigma değişikliğinin ne olduğunu kısaca açıklamak gerekir. Mevcut paradigma belli bir toplum tarafından kabul edilen varsayımlar dizisidir, gözlemlenen olguya yeterli açıklamayı veremediğinde yıkılır. Yeni bir bilgi yardımıyla bakış açınızın yani paradigmamızın yanlış göründügünü anlamak, yeni bir paradigma kurmamıza yol açar (Reis, 2018). Yeni paradigma kurmak için eskinin eksikliğini, yanlışlığını veya yetersizliğini görmemiz gerekir. Bu da elbette birçokları tarafından kolay kabul edilebilir bir şey değildir. Paradigma değişiklikleri genelde sancılı süreçleri bünyesinde barındırır.

Alman felsefeci Arthur Schopenhauer'in; 'Bütün gerçekler üç aşamadan geçer. Önce alay konusu yapılır, sonra şiddetle karşı çıkılır, nihayetinde tartışmasız olarak kabul edilir' sözleriyle özetlediği bu süreç, belge/bilgi yönetimi süreçlerinin yeni bir paradigmaya sahip olması noktasında da geçerliliğini koruyacaktır. Genel hatlarıyla şu anda önerilen paradigma değişimleri, çoğu profesyonelce bazılarının fantezisi olarak algılanıp tanımlanacaktır. Alaydan sonraki basamakları tamamlayacak süreçler de arkadan gelecektir. Bu bir önyargı olmaktan öte zaman zaman konunun profesyonelleriyle yapılan görüş alı̧ verişinden edindiğim izlenimlerdir.

Konuyu profesyonellerin dışına taşıdığınızda ise durumun vahameti artmaktadır. Dijitalleşmeye, onun getirip götürdüklerine bir gerçeklik ve süreç olarak bakmaktan ziyade ürün olarak bakan, ama belge/bilgi yönetiminin de hem etkinlik hem de etki ağında yer alan bu kesimin köklü değişimleri, alaycılıkla karşılayıp önemsemedikleri her gün rastlanılan rutinlerdendir.

Belge/bilgi yönetiminde paradigma değişikliği için öncelikle konuyla ilgili zihniyet değişikliğine gidilmesine ihtiyaç vardır. Bu disiplin artık yalnızca geçmişle bugünü birleştirip geleceğe bilgi materyalleri taşımanın ötesine geçmek zorundadır.

\subsection{Dijital/Elektronik Dünyada Belge/Bilgi Yönetimi ve Liderlik Olgusu}

Belgenin/bilginin yönetilmesi süreçleri dijital dünyanın lider olgusudur. Bu noktadan donanım veya yazılımı önemsememek gibi bir anlam çıkartılmamalıdır. Donanım ve yazılım dijital dünyanın olmazsa olmayanları, ancak sürecin içerisinden belgeyi/bilgiyi ve bunun yönetim metodolojisini çıkardığınızda bunların ortaya konuluş sebepleri de buharlaşıyor. Dijital dünyayı temellendiren, yaşayabilir yapan, herkesin, her şeyin bilgisine erişmek, sınıflamak, bunları değerlemeye tabi tutarak analiz etmek, sınıflar arası madencilik yapmak, ayrıştırmak, paylaşmak, dağıtmak, korumak, hızla yeniden bilgi üretip, elde edip süreci tekraren işletilebilir kılmaktır.

Bunun için de geçmişin bilgisini geleceğe taşımaktan daha öte bir adıma ihtiyaç vardır. Her dönem kendine has temel farklı özellikler taşır: Geleceğe taşınabilen geçmiş ve geçmiş kadar belirgin ve materyal olmayan bir olasılıklar sahası olan gelecek (Otto Scharmer'den aktaran Göksel, 2020).

Liderlik kavramının günümüzdeki değişim ve dönüşümünü Harvard Business Review Türkiye Dergisi'nde Beste Göksel'e değerlendiren Scharmer (2020), geleneksel liderlikte gelecek anlayışının yer almadığını, geleneksel liderlerin geleceğe bakma şeklinin, geçmişi kontrol edip anlamaktan ve bunu geleceğe taşımaktan geçtiğini, birçok insan için ise geleceğin, o ya da bu şekilde geçmişin bir uzantısı olduğunu ifade eder. Stabiliteyle tanımlanan bir zamanda yaşasaydık bu yaklaşımın işe yarayabileceğini görüşlerine ekleyen Scharmer, bir yıkım çağında yaşadığımızı, bu yaklaşımın ise bu çağda geçerli olmadığını da belirtir. Zihin yapısı dönüştürülmeksizin sistemi değiştirmeye çalışmanın başarısızlık getireceğini, zira bu durumda aynı insanlar, farklı yapılarda aynı sorunları ortaya çıkaracaklardır, tespitini de ilave eder.

Canan ve Acungil de (2018, s.82), teknolojinin çok yüksek değişim hızı sebebiyle tarihin akışının hızlandığını, geçmişi algılayabilme ve geleceği tahmin edebilme gücünün düştüğü düşüncesinde olduklarını söylerler. Aynı yazarlar (2018, s.150), geleceğe yönelik öngörülemeyen büyük değişimlerle veya bir anda ortaya çıkan ve her şeyi değiştiren gelişmelerle ilgili olarak Nassim Nicholas Taleb'in Siyah Kuğu adını verdiği, nadir ve öngörülemeyen aykırı olayların aşırı etkisine ve insanın bu olaylar için geriye dönük olarak basit açıklamalar bulma eğilimine göndermede bulunurlar. Taleb (2019, ss. 910) 'Siyah Kuğu Olasılıksız Görünenin Etkisi' adlı kitabının önsözünde, Siyah Kuğu adını verdiği olgunun temelinde gözlem ve deneylere dayalı öğrenmenin ciddi boyutta sınırlamalarının olduğuna ve 
bilgimizin kırılganlığına dikkat çeker. Tek bir gözlem (...) genel kanıyı geçersiz kılabilmektedir. Rastlantısal olana, özellikle de büyük sapmalara karşı da körüzdür. Bu, olasılıksız görünen ve üç temel özelliği olan bir olaydır: Öngörülemez; çok etkilidir; gerçekleştikten sonra onu daha az rastlantısal ve daha öngörülebilir hale getiren bir açıklama uydururuz.

Elektronikleşen, dijitalleşen ve buna sadece zihinsel olarak değil, organik olarak da bağımlı hale gelen dünyaya hazırlıklı, alışa alışa geldiğimiz söylenemez. Orta yaş ve üstü kuşağın hayatının her safhası bu süreçte büyük sapmalarla sarsılmıştır. Mesleklerin birçoğunun da bu sapmadan nasibini aldığ 1 bir gerçektir. Dijital dünyaya dair gözlemler, bireyselden kamusal alana ve oradan küresele erişen hareketlilik, duygu, düşünce ve eylem değişiklikleri konusunda yapılacak tarafsız gözlemler, mesleki paradigmalar açısından bazı genel kanıların yine mesleğin geleceği açısından hızla değiştirilmesi gerçekliğiyle bizi yüz yüze bırakmaktadır.

\subsection{Gelecekte Var Olabilmek İçin Yapısal ve Zihinsel Değişim İhtiyacı}

Bu rota üzerinde hareket ettiğimizde ve günümüz koşulları göz önünde bulundurulduğunda, belge/bilgi yönetimi disiplinin eğitim alanının konumlandırıldığı kütüphanecilik zeminin değiştirilmesi hususunda, ciddi bir yapısal ve zihinsel değişikliğe ihtiyaç vardır. Yani günümüzün ve geleceğin arşivcisi, belge/bilgi yöneticisi bu dünyanın gerçekliklerine uygun fabrika ayarlarıyla donatılmalıdır. Teknolojinin doğasıyla birlikte, onun oluşturduğu sosyolojiden psikolojiye, hukuktan iktisada vd. alanlara yönelik yeni atmosfere, felsefeye, iş yapış bilgi ve becerisine sahip olmak gerekiyor. Eğitim içeriğimizin ve pratiğinin ortaya çıkardığı bir ürün olarak niteleyebileceğimiz meslek grubu, bu ürünlere talip olacak piyasanın isteklerine, ihtiyaçlarına cevap vermelidir. Bu çerçevede söz konusu alanın eğitim içeriğinin ve beceri setinin hızla güncellenmesini sağlamak, yeni dünya gerçekliklerini, eğitimimizin içeriklerinin ana omurgası ve iskeleti haline getirmek zorundayı.

Örneğin, 'ihs teknoloji’ye ait web sayfasında yeni dünya gerçekliklerinden birisi olan "hiper bütünleşik mimari” şu cümlelerle açıklanmaktadır: Son dönemlerin önemli bir teknik özelliği olan, karmaşaya, performans artımına, güvenlik sağlamaya, esnekliğe, verimliliğe, basitliğe çözüm olarak önerilen "hiper bütünleşik mimari” altyapı sistemi, veri merkezinizde yönetmeniz gereken sunucu, veri depolama, yedekleme, sanallaştırma, ağ gibi katmanları tek bir yapı üzerine toplayıp kullanmanızı, yönetmenizi ve raporlamanızı sağlayan bir sistem olarak revaçtadır (2020).

İşte arşivci, belge/bilgi yöneticisi de yeni yapılanmalarda bu teknolojik bütünleşik sistemin mesleki olarak yansıması olmalıdır. Mesleki bilgi ve beceri setiyle çalışma alanında, birçok katmanı tek bir yapı olarak yönetilebilir kılan bir çalışan olmak durumundadır. Arşivcilerin, belge/bilgi yöneticilerinin geleceğini, elde ettikleri, diplomaları, sertifikaları değil, dünyanın yeni gerçekliklerine uyumlu bilgi ve beceri setleri belirleyecektir.

Çünkü gelecek alışılmış ve öğrenilmiş bir takım becerileri rutine dayalı arka arkaya gerçekleştirmekten ziyade, hayatı sürdürebilmek hatta var olabilmek için, devamlı değişen, akışkan, dinamik yenilikleri yönetilebilir ve kullanılabilir kılanların üzerinden yürüyecektir. Yapay zekânın, nesnelerin internetinin, makine öğrenmesinin bugün bile etkisini gösterdiği çalışma hayatında, gelecekte birçok mesleğin ortadan kalkacağı, birçok işin makineler tarafından insanların elinden alınacağı gerçekliğiyle karşı karşıya olduğumuz bir vakıadır. Bu tehlikeden kendisini kurtaracak olanlar ise söz konusu teknolojileri yönetilebilir kılanlar, onlar için yüklenecek bilgileri belirleyenler, bilgilere anlam katacaklar, bu anlamları tekrar yeni kullanım alanlarına taşıyanlar olacaktır.

Yani yalnızca bazı hazır bilgileri öğrenip uygulayanlar değil, dinamik ve devamlı gelişip yenilenen, evirilen hayat için eğitilenler ayakta kalmayı ve kendisine bir yer edinmeyi becereceklerdir. Bunu bugün gerçekleştirmek üzere harekete geçmesek de şartlar bizi buna maruz bırakacakmış gibi duruyor. Elbette bunda erken davrananlar yine kazançlı olacaktır. Burada Taleb'in (2019), Siyah Kuğu metaforuna gönderme yapmak isterim. Mesleğin evirildiği noktaları biz öngöremezsek bu alanın dışından gelecek öngörülmezlikler bizi değişime zorlayacak, ancak bu bizim kontrolümüz ve hesaplarımız dışında gerçekleşecektir.

Doğada da değişen koşullara ayak uyduran canlıların ayakta kalıp avantaj yakalaması gibi değişen şartlara göre alışkanlıklarını, içeriklerini, hareket tarzlarını değiştiren meslekler (insanlarda buna paradigma değişikliğini de ekleyelim) 'dijital küresel ağlaşmış’ dünyada avantajlı konuma geçecektir. 
Arşivciler ve belge/bilgi yöneticileri olarak bu yeni dünyada mesleğimizi domine etmenin yollarını bulmazsak, büyük ihtimalle mesleğimizin, hızla başka meslek grupları tarafindan yutulup hazmedildiğini göreceğiz.

Arşivcilik ve belge/bilgi yönetimi muhakkak, hem daha da önemsenerek devam edecek, ama hangi meslek alanı üzerinden, hangi değerler dizininin sınırları içerisinde yol alacağını şu anda tam anlamıla kestirebilmek güçtür. Bu sebeple bugünler harekete geçme noktasında önemlidir. Arşivcilik ve belge/bilgi yönetiminde uygulama zemininin en önemli halkasını oluşturan kamuda, mesleğin profesyonellerinden daha çok tarih, Arapça, ilahiyat, diğer filoloji disiplinleri vb. gibi sosyal bilimler alanı mezunlarının istihdam edildiği, birçok sosyal bilimler mezunu tarafından da arşivciliğin çalışma sahası olarak görüldügü dikkat çekmektedir.

Bu bir noktaya kadar kabul edilebilir ve muhakkak olması da gereken bir durumdur. Ancak sahanın tümünün, arşivcilik ve belge/bilgi yönetimi mezunlarına yer bırakmayacak şekilde, farklı alan mezunları tarafından doldurulması yanlış bir uygulamadır. Arşivcilik, belge/bilgi yönetimi mezunlarına kamusal çalışma hayatında ayrı bir kontenjan açılmalı, pozitif ayrımcılık hayata geçirilebilmelidir. Çalışma hayatının bir gerçeği olan bu husus makalenin ana konusu olmamakla beraber kısaca bir tespit yapılması doğru olacaktır. Bu makalede özellikle arşivcilik ve belge/bilgi yönetiminin akademik düzeyde ilerlemesi gerektiği düşünülen yeni rotası belirlenmeye çalışılmıştır.

\section{3. "Kütüphanecilik $>$ * Belge/Bilgi Yönetimi” mi?}

Ülkemizde arşivcilik ve belge/bilgi yönetimi eğitimi başladığından bugüne kütüphaneciliğin içinde ya da altında konumlandırılmaya çalışılmıştır. Bunun arşivcilik ve belge/bilgi yönetimi disiplini yeterince algılanmadan kütüphaneciliğin bir çalışma alanı olarak görülmesinden kaynaklandığı söylenebilir. Oysa teknik olarak doğuş ve gelişme çizgisine baktığımızda, arşivcilik ve belge/bilgi yönetimi kütüphaneciliğin altında yeşermiş ve kendine hayat alanı bulmuş ne bir disiplin ne de bir çalışma alanıdır. Özdemirci (2017, s. 221) de, "Belge yönetimi, kütüphaneciliğin içinden doğmamıştır; arşivin tarih biliminden doğmadığı gibi. Ancak belge ve arşiv yönetimi disiplini/disiplinleri birbirini tamamlayan süreçler bütünü olarak günümüzde disiplinlerarası nitelikleriyle, disiplinlerarası ilişkileri ve yaklaşımlarıyla dikkat çekmektedir" vurgusunu yapmaktadır.

Buradan hareket ettiğimizde şu önermede rahatlıkla bulunabiliriz; yüksek öğretim sistemi içindeki yapılanmadan kaynaklanan uygulamada arşivcilik ve belge/bilgi yönetimi "Kütüphanecilik" disiplinin bir alt alanı olarak konumlandırılmış gibi görünse de ya da ülkemizde böyle algılansa da bu konumu ile dijitalleşen dünyada artık gelişimini ve etkin işlevselliğini sağlayamaz.

$\mathrm{Bu}$ görüşe yoğun ve sert tepkilerin geleceğini düşünüyorum. Köklü olan, gücü elinde bulunduran mesleki formasyon kütüphaneciliktir ve gücü elinde bulunduranın statükoyu korumak istemesi, hatta savunma refleksi içerisinde onu kutsaması hayati bir gerçeklik olarak önümüzde durur. Hiçbir güç unsuru, konfor alanının zedelenmesinden hoşlanmaz. Ayrıca insanların yerleşik alışkanlıklarını değiştirmelerinin zorluğu sosyal ve antropolojik bir gerçek olarak bilinir. Bu çerçevede temel sorun, teknolojinin, dijitalleşmenin getirdikleri yanında bunların etkisiyle oluşan yeni sosyal, toplumsal, psikolojik, ekonomik ve güvenliğe vb. dair hususlara da belge/bilgi yöneticilerinin vakıf olup olmadıkları, bu değişiklikler, yeni gerçeklikler doğrultusunda mesleki bilgi, beceri setlerini ve alışkanlıklarını değiştirmeyi arzu edip etmedikleridir. Öncelikle zihni yapımızın, paradigmalarımızın buna uygun olması veya uyum sağlaması çok önemlidir.

Bugünden sonra, arşivcilik ile belge/bilgi yönetimi disiplinin ve uygulama sahasının bu alan mezunlarınca yerine getirilmesini, etkin olarak var olmasını veya kaybolmaya doğru gidişini, teknolojik gelişmelerden, dijitalleşmeden daha çok bugünkü meslek profesyonellerinin, akademisyenlerin ve yöneticilerin eğilim, tercih ve öngörü kabiliyetleri belirleyecektir. Dünyayı saran, sarmalayan yeni gerçeklikler, konjonktürel yapılar, geleceğe yönelik olarak mesleğin teknolojiyle olan alışverişi, bu dünyaya uyum sağlayıp eklemlenmesiyle birlikte hayata dâhil olmasını sağlayacak olan temel kitle budur.

\footnotetext{
* Matematikte bu işaretin solunda olan şey büyüktür anlamına gelir.
} 
Konuya bu doğrultu üzerinden bakarak arşivciliğin, belge/bilgi yönetiminin, kimilerine göre kütüphaneciliğin içerisinden doğduğu düşüncesi ülkemizde ya da ilgili camiada yaygın hâkim görüş olarak görünse de farklı işlevsellikler, farklı gelişmişlikler, farklı hukuki, yapısal ve kültürel kodlarla donandığı tespitini yapabiliriz. Etkinlikleri, iş ve işlemleri, sorumlulukları, kapsama alanları, neticede ortaya çıkan hukuki durumlar bu farklılığı gözler önüne serer.

“Günümüz şartlarında belge ve arşiv yönetiminin yükselmesi kaçınılmazdır. Belge ve arşiv yönetimi alanında eğer bilgi ve belge yönetimi bölümleri söz sahibi olacaksa, belge ve arşiv yönetimi alanında kendini değerlendirmeyi koşulsuz kabul etmeli, yeniden incelemeli; teknolojideki, bilişimdeki gelişmeleri ve bu alanlarla olan belge ve arşiv yönetiminin ilişki boyutunun farkında olarak yeni yaklaşımlar, yeni kuramlar üretmelidir. Geleneksel kütüphaneciliğin, geleneksel arşivciliğin ötesine geçebilmelidir. Belge ve arşiv yönetimi farklı boyutlarda kendini gösteriyor, yolunu buluyor ve varlığını sürdürüyor. Önemli olan bu yükselen değerin farkında olmak ve kaybetmemektir" (Özdemirci, 2017, s. 225).

Kütüphanecilik mesleği de bir bilgi mesleği olmakla birlikte arşivcilikle içerik, uygulamaları ve neticeleri açısından ayrı sonuçlar ve etkiler doğurur. Kütüphaneden kaybolan bir yayının ortaya çıkardığı sıkıntı ile arşivden kaybolan bir belgenin sıkıntısı ve sonuçları aynı değildir. Bir kütüphaneden istediği kitabı zamanında veya hiç alamayan bir kullanıcının uğradığı zarar ile bir arşivden istediği belgeyi, örneğin işe başvurmak için istediği not dökümünü veya çıkış belgesini zamanında veya hiç alamayan kişinin uğradığı zararın sonuçları ve etkilerini aynı kefede tartamazsınız. Dijital dünyada ağlar üzerinden kitaplara, metinlere, dokümanlara erişmenin çok kolay olduğu günümüzde bu sıkıntıyı birçok kullanıcı hissetmeyebilir. Ancak dijital erişime açılmamış veya sınırlı açılmış arşiv belgelerine erişememek ciddi hak ve hukuk yönünden kayıplara sebep verebilir.

$\mathrm{Bu}$ çerçevede bir kurumda veya özel bir işletmede bulunan kütüphanenin görev ve fonksiyonları ile arşivlerin görev ve fonksiyonları, etkiselliği ve etkileşimi de birbiriyle aynı değildir. Kütüphanelerin hayatın her alanıyla ilgili veya tüm disiplinlerle ilişkisi bilgi, kitap, yayın, doküman temini olarak görülürken, arşivler iş, işlem, hak, hukuk yönünden delil olma vasfını bünyesinde barındıran belgeleri kapsar. Arşivlerin kurumlarda görev ve fonksiyonlarına genel hatlarıyla bakıldığında da farklılıklar kendisini hemen gösterir. Kurumlarda belge/bilgi yönetimi, kütüphanecilikten farklı bir süreç olarak kütüphanenin idari işlemlerini de kapsamına alacak şekilde her personelle ve her birimle tek tek işlevsel ve hukuki ilişki de kurarak sistemli şekilde yürütülür.

Tüm bu açıklamalardan hareket ederek şu tespiti yapmamız da mümkündür: Fonksiyonları, ilişkileri, ilintileri, etkileri, etkileşimleri ve kapsama alanları bakımından kütüphanecilik mesleği statik ve taktiksel; arşivcilik, belge/bilgi yönetimi mesleği ise dinamik ve operasyoneldir. Burada tekraren özellikle vurgulamak istediğim şey, mesleklerin önem ve değeri üzerinden bir değerlendirme yapılmadığıdır. Bu tespitler tamamen mesleki fonksiyonlara ve yukarı cümlede sıraladığım hususlara yöneliktir.

Ayrıca arşivcilik ve belge/bilgi yönetimi hususunda benim bir tespitim de şudur: Bu meslek teknoloji ile idari ve hayata dair diğer alanlar arasında bir 'kenar' görevi görmektedir. İdari yapının bütün unsur ve aşamaları, bireyselden devlete kadar giden bütün yapısalların belgesi, bilgisi ilgi ve çalışma alanıkken, bunun, sistemlere, teknolojik ürünlere aktarılması, güvenlikle yönetilebilir, erişilebilir, kullanılabilir kılınması ayrı bir ilgi ve icraat alanıdır. İște meslek, bu iki alan arasında geçişleri sağlayan, bu geçişin sistemik yürütülmesini temin eden bir kenar görevi görmektedir. Hem sınır belirler ancak sınır kadar keskin olmadığından hem de iç-dış geçişkenlikle içerik oluşturur. Bir şeyin kenarı belli olmadan onu bir kalıba sokup sınırlayamaz, şekillendiremez, sınırlayıp şekillendiremeyince nitelik veremez, ölçüp biçemezsiniz. Bu çerçevede arşivcilik ve belge/bilgi yönetimi bilgiye dair her şeyi hayata sistemik dâhil ederek sınırları, nitelikleri de belirleyen, içerik oluşturup anlamlandırmaya, analize ve gelişmeye yol açan bir işlevselliğe sahiptir.

Özdemirci (2017, s.220), belge yönetimi-arşiv ilişkisini ifade eden, belge yönetimi ve arşiv alanının boyutunu, farklı disiplinlerle ilişkisini gösteren farklı kavram ve cümleleri ve bu alanla ilişkili olarak değerlendirdiği kavramları gruplandırarak şu şekilde sıralar:

- Yönetimsel etkiler, siyaset, hukuk, şeffaflık, açık bilgi 
- Gizlilik, yazışmanın mahremiyeti, kişisel bilgi

- Kurumsal bilgi, erişilebilirlik, yetkili erişim, yetkili paylaşım, istihbarat

- Kurum arşivleri, kurum belge merkezleri, kurum veri merkezleri

- Teknolojik etkiler, bilişim, elektronik, veri iletimi, veri merkezleri, bulut sistemler

• Güvenlik, güvenilirlik, süreklilik, sürdürülebilirlik.

Özdemirci ve Aydın (2008), kuruluşlarda bilginin bu süreçlerle irtibatını da işlemlerle, kavramlarla, yorumlarla, düşüncelerle, gözlemlerle, önyargılarla ilişkilendirir. Kurumlarda bilginin, kuruluşların ihtiyaçları doğrultusunda şekillenip, üretilip, depolanarak kullanıldığı tespitinde bulunurlar. Bu nedenle de kurumsal bilginin, kurumsal gelişmeler doğrultusunda ortaya çıkan, planlı, düzenli ve sürekli bir çalışmayı gerektiren bir sürecin ürünü olduğunu belirtirler.

Külcü (2006, s. 207) de belge yönetiminin nasıl ortaya çıktığına odaklanır ve belge yönetiminin 20 . yüzyılın ortalarından itibaren kurumsal yap1, resmi iletişim aracı olarak belge sistemleri ve dolayısıyla kurumsal bürokrasinin etkinleştirilmesi üzerine çalışmaların ürünü olarak doğduğunu ifade eder. Görüldüğü üzere kurumsal bürokrasi, resmi iletişim ve dolayısıyla hukuk belge yönetiminde hep ön plandadır. Bu çerçevede kurumlarda belge yönetimi çalışmalarının en önemli hedefleri arasında, kurumsal işleyişi üretilen belgelere dayalı olarak denetim altına almak yer almaktadır.

\subsection{Akademik Hayatta Yeni Bir Rota Belirlemek}

$\mathrm{Bu}$ noktadan hareket edildiğinde görülen odur ki, belge/bilgi yönetimi ve arşivleme süreçleri idari yapının ayrılamaz bir parçasıdır. İdari yapıdan belge/bilgi yönetimini, arşivlemeyi kaldırdığınızda kurumsal meşruiyet de ortadan kalkar. İdari yapının bir parçası olan süreçleri sistemleştiren bir faaliyetin söz konusu olduğu belge/bilgi yönetimi disiplini bu sebeple edebiyat fakültelerinin kapsamından çıkartılarak bugün için ve yakın gelecekte varlıklarına şahit olacağımız bilişim/teknoloji ile özdeşleştirilecek idari bilimler fakültelerinin içerisinde yapılandırılmalıdır. Yarının getirdikleri farklı kümeleşmeleri, yapılanmaları ve pozisyonları da gerektirebilir. Bu çerçevede, dönem dönem eğitim programlarına bir takım farklı dersler koyarak, yani asli unsur olarak kökten değişim yapmadan, ana ilkeler ve içerikler hakkında yenileşmeye gitmeden, adeta bir takım yamalarla, sökükleri tamir ederek yıpranmış olanı yenilemek mümkün olmayacak, bu ancak kullanım süresini belki biraz daha uzatacaktır. Yani belirli bir alanın kısıtlarıyla* mesleği çerçevelendirmek, içini doldurmakla uğraşmak yerine, çokluklar, ilişkiler, birliktelikler dünyasının geniş imkânlarına yaslanmalıyız.

Konu o kadar köklenip diğer alanlarla sarmallaşmıştır ki, mesleki veya akademik olarak artık yalnız bir disiplinin kolları altında belirli bir ders yüküyle, gerçek iş dünyasında faydasız veya eksik kalacak bilgi birikimiyle geçiştirilemeyecek kadar çetrefillidir. Bugün bu meslek için sorun belirli bir bilgi birikimine erişim, bu alanla ilgili bilgilenme ve beceri kazanmaktan çok daha öteye taşmıştır. Günümüzde olay, çok alanla ilişki, irtibat, bunun getirdiği çoklu bilgi ve beceri kazanma sorunsalı üzerinden yürümektedir.

Burada, bugün için idari bilimler içerisinde eğitime devam etmek, ifadesine dikkat çekmek isterim. Çünkü biz geleceği hayal ederken bugünü değerlendirip bugünle bir karşılaştırma, ölçümleme yapıyoruz. Fakat çok büyük ve köklü değişikliklerin olduğu dünyada yapmamız gereken ise, bugünkü ipuçlarından yola çıkarak geleceğe yönelik, her yeni gelişime ve sapmaya uyarlanabilecek esnek bir yapısallık ortaya koymaktır. Oluşabilecek gelişmeleri, değişimleri ne kadar önceden fark edebilirsek hazırlıklarımızı o kadar iyi yapabileceğimiz gibi, eklemlenme ve uyum sağlama süreçlerini de o kadar sıkıntısız atlatabiliriz. Bu disiplinin gelecekte belki bir teknik bilimler fakültesinin içerisinde veya disiplinler üstü bir alan olarak lisansüstü programlarda konumlanması gerekecektir. Bu noktada en önemli husus, meslek profesyonellerinin ve karar vericilerin yeniliklere uyarlanabilirlik ölçeğinde, dönüşüme, değişime liderlik edecek bir paradigma değişimine, hızına ve çevikliğine yatkın olmasıdır.

\footnotetext{
* Kısıtlar: Her sistemin amacını gerçekleştirme sürecinde performansını (tüm sistemin çıktısını) sınırlayan herhangi bir şey olarak tanımlanmaktadır. Erişim adresi: https://nenedir.com.tr/kisitlar-teorisi-theory-of-constraints-nedir/
} 
Bugün için idari bilimler fakültesinde yer alacak belge/bilgi yönetimi bölümünün eğitim içerikleri de bu çerçevede yeniden oluşturulmalıdır. İşletme, kamu yönetimi, iktisat gibi disiplinlerle birlikte, işin geldiği nokta itibariyle, elektrik-elektronik mühendisliği, bilgisayar-yazılım mühendisliği, endüstri mühendisliği, istatistik gibi teknik bilimler alanından da alınacak derslerle ders programları zenginleştirilmelidir. Ayrıca genel dilbilim, hukuk, psikoloji ve sosyoloji disiplinlerinden de seçmeli derslere yer verilmelidir. Unutulmaması gereken çok önemli bir önerme, binanın sağlamlığının, dayanıklılığının onun oturduğu temelin sağlamlığıyla doğru orantılı olduğudur. Temelde bozukluk, eksiklik, hatalar varsa bina da o kadar kolay yıkılmaya, hasara açıktır.

Geleceğin başarılı meslekleri, eldeki mevcut bilgileri, imkânları, gelişmelere yönelik yeni bilgiler ve imkânlarla harmanlayan, birbiriyle birleştirip devamlı değişen, dinamik yapıda bir kompozisyon kuranların olacaktır. Bugün belge/bilgi yönetimini, arşiv bilimini de doğası itibariyle, tek bir katmanla tarif etmek, her hangi bir disiplinin altında yardıme bir alanda toplamak, tek bir disiplinin sinırlarıyla çevrelemek mümkün değildir. Bulunduğumuz çağ itibariyle arşivci/bilgi-belge yöneticisi disiplinlerarası bir gezgindir. Arşivcinin kamu idaresindeki konumu Mevlana'nın, meşhur pergel metaforundaki ifadeye benzetilebilir: "Pergelin iğneli ayağı sabittir benim dinimde, ama diğer ayağımla yetmiş iki milleti dolaşırım". Arşivci de mesleki bilgi birikimini edinirken, eğitimini alırken birçok disiplin alanından faydalanmalı, meslek hayatına atıldığında ise çalıştığı kurumla ilgili bilgilere, tüm idari prosedürlere ve uygulama süreçlerine vakıf olmalı, ama diğer ayağıyla da dünyayı dolaşabilmelidir. Belge, yani bilgi taşıyan materyalin içerikleri, üretim aşamaları, saklanması, saklama süreleri, tekraren hizmete sunulması gibi süreçler arşivcinin mesleki sorgulama alanıdır (Torunlar ve Özdemirci, 2014). Elektronikleşen, dijitalleşen dünyada bu sorgulamayı yapmak artık hayati bir ihtiyaç olmuştur.

\subsection{Yeni Bilgi ve Beceri Setleri Geliştirmek}

Belge/bilgi yönetimi profesyonelleri, her şeyden önce kendilerine şu soruları sormalıdır: Mesleki olarak dijital dünyaya yönelik stratejim nedir? Belge/bilgi yönetimi bugün geldiği noktadan bugünkü performansıyla nereye gidebilir? Dijital dünyada belge/bilgi yönetimi nerede, nasıl, hangi pozisyonda kendisine yer bulacaktır?

Dijitalleşme, yapay zekâ vb. oluşumlar binbir emekle, zahmetle elde edilen becerilerimizi elimizden alıp, bizden daha iyi yapabilir hale doğru yol alırken, meslek ne olacak, nasıl yapılacak veya mesleki bilgi ve becerilerime ihtiyaç hissedilecek mi?

$\mathrm{Bu}$ soruların bazı belge/bilgi yönetimi profesyonellerini paniğe sokacağını düşünüyorum. Bunu öncelikle kendimden biliyorum. Dijital ortamlar, ağ yapıları, elektronik belge/bilgi yönetim modelleri ortaya çıktığında, mesleğin kaybolduğu endişesini şiddetle hissetmiştim. Bu çerçevede tüm profesyonel belge/bilgi yöneticileri dijital teknolojilerin ve iş modellerinin kendi iş yapma biçimlerinde varoluşsal bir tehdit oluşturduğuna inanmakta sonuna kadar da haklıdırlar. Ancak bu varoluşsal tehdidi, kendimizi içine bir şekilde hapsettiğimiz dar bir alanda kapalı kalarak bertaraf edemeyiz. Disiplinler arası bir yaklaşımla yeni paradigmalar belirleyerek kendi ellerimizle mesleği geliştirip dijital hayata dâhil edebiliriz.

Aslında bugünkü olaylar, olgular, gelişmeler, dönüşümler zamana yayılsa da, yapısal adımlar atıldığında mesleki olarak daha fazla fayda elde edilebileceğini de ortaya çıkarmıştır. Çünkü dijital/elektronik dünyanın çekirdeğinde belge/bilgi yönetimi süreçleri vardır. Ancak bu noktada belge/bilgi yöneticilerinin nereye gitmek istediklerine dair bir vizyonları olmalıdır. Yeni dünya gerçeklikleri belge/bilgi yönetiminin mevcut teknik ve idari bilgi setiyle fazlaca uyum göstermemekte, bu bilgi ve beceri seti, kamu veya özel sektörde arzu edilen düzeyde etkin olabilmek için bu haliyle yetersiz gibi görünmektedir.

Şunu hepimiz istisnasız kabul ediyoruz ki günümüz dünyasında yeni teknolojiler, süreçler var olan, bilinen iş, işlemleri, değerleri, materyalleri farklı bir kullanım biçimine ve etki gücüne çeviriyor. Elektronik ve dijital dönüşüm içeriğini, yapısını, görev tanımlarını, etkinliğini, etkileşimini ve iş yapış biçimlerini o kadar hızlı değiştirmektedir ki bu değişim, sürekli gelişim, yenilenme ve temeli şimdilik idari bilimler üzerinde olmak üzere disiplinler arası etkinliği şart koşmaktadır. Talip olduğu pozisyona, yapacağı işe yabancı kalacak bir yapı, dijital dünyada kendisine yer bulamama tehlikesi ile karşı karşıyadır. 
Mesleklerin, uzmanlıkların alt bölümlere ayrıldığı dönemlerden itibaren meslekler arası üstünlük yarış1 var olagelmiştir. Bürokrasi içerisinde veya özel sektörde yönetim mekanizması içinde etkin ve önemli olmayla ilgili faaliyetler, mücadeleler ile bu mücadele ve faaliyetlerde hedefe erişim için bilgi üretme, bunu eyleme dökme mekanizmaları gerekli olmuştur, bu gereklilik şekil ve içerik değiştirerek olmaya da devam edecektir. Bu çerçevede belge/bilgi yönetimi çalışanlarının kendisini yeterli düzeyde geliştirememesi, mesleki alanının başka meslek elemanlarınca işgal edilmesi anlamına gelir. Tabiat boşluk kabul etmemektedir.

Dijital çağın getirdiği otomasyon, ağlar, verimlilik, sınırsızlık, zamansızlık, mekânsızlık bunları daha da etken hale getirebilecek yapay zekâ kullanım imkânları, akla gelebilecek her yapıda veya piyasada birçok disiplinle işbirliği yapmayan, klasik dar bir mesleki alanda sıkışacak gruplara hayat hakkı tanımayacak gibi görünmektedir. Önümüzdeki yıllarda daha az sayıda insan emeğiyle, birçok şeyi yapabilmek mümkün olacaktır. Farklı şeyler olmazsa, yakın tarihte kamuda veya özel sektörde, henüz adı konmamış dönüşümlerle, bilinen çalışma kurgularından çok farklılaşmış, evrilmiş kurgular hayata geçecektir.

Mesleğin yeni adaylarına bugünkü dünyada veya yakın gelecekte kullanma imkânları olmayan bilgiler yükleyip bunlar doğrultusunda beceriler kazandırmaya uğraşmak yerine, dijitalleşen dünyayı ve öncelikle kendi insanından, toplumundan başlayarak dünyanın geri kalanını anlayacak, bilecek, değerlendirecek, bunları üretici boyutunda devreye sokacak yeni paradigmalarla, bilgi ve beceri setleri ile donatmaya çabalamalıyız.

$\mathrm{Bu}$ noktada Pareto Yasasın1* hatırlamamızda fayda var. Pareto Yasas1, kütüphane ve bilgi bilimi literatüründe, genellikle 80/20 kuralı olarak geçmekte olup bu kural, ürünlerin \%80'inin, kaynakların \%20'si tarafından gerçekleştirilebileceği fikrine dayanmaktadır (Yılmaz, 2005; Çağlar, 2020).

Elbette ilke kesin olarak 80 ve 20 sayılarının kendisi üzerine odaklanmıyor. Girdiler ve çıktılar arasındaki dengesizlik ilişkisi 65/35, 75/25, 70/30 veya aradaki sayıların herhangi bir kümesi şeklinde de olabilir. Ve yüze tamamlanması da her zaman gerekli değildir, yüz sadece algılamada kolaylık sağladığı için kullanılmaktadır. İlke şunu diyor: Nedenler ve sonuçlar arasındaki dengesiz orantı kaçınılmazdır. Unutmayalım bu ilke yaşamdaki dengesizlik prensibini anlamamıza yardımcı olduğu kadar, aslında hayatımızdaki ve günlük yaşantımızdaki birçok etkinin yalnızca $\% 20$ kadarının gerçekten önemli olduğuna, kişisel zaman yönetimimiz için bu \%20'lik kısma ağırlık vermenin gerekliliğine de vurgu yapıyor (Çağlar, 2017).

$\mathrm{Bu}$ yasadan hareket ederek biz yeni bir zihniyet ve içerikle yetiştirdiğimiz gençlerin \%20'sinde başarılı olursak mesleğin çok ileri safhalara taşınabileceğini de rahatlıkla söyleyebiliriz. Mesleğin üretici boyutu toplumsal gelişime de ciddi oranda etki edecektir.

İşte bu yeni dünyada ilerlerken mesleki formasyon doğrultusunda yeni iş süreçlerinde hangi ölçütlerin kullanılacağ hayata dâhil edileceği ve mesleki düzlemde yeni rakiplerin kimler, hangi gruplar olacağı gibi konularda çalışmalar yürütülmeli, bu çalışmadan elde edilecek veri setlerinin analiz sonuçları eğitim programlarına entegre edilmelidir. Bu çalışmaların sonucunda ortaya çıkan veriler, bilgiler içselleştirildikçe kamuda veya özel sektörde yeni konumlanmaya, statü değişikliğine, rekabet ortamına ve geleceğe dair belirlenecek uzun vadeli diğer hedeflere ilişkin anlayışlar da gelişip değişecektir.

Kısa bir süre öncesine kadar kamu kurum, kuruluşlarının -özel şirketler için de geçerli olmak üzerekurumsal, faaliyet veya hizmetlerinin sınırları çok belirgindi ve herkesçe anlaşılıyor, bu doğrultuda da işler yürütülüyordu. Ancak dijital teknolojiler daha önce kurumlar içerisinde yapılan birçok işi ağlar üzerinde çözmeye imkân vererek bu durumu ciddi biçimde birbirinin içerisine geçirerek basitleştirirken aynı zamanda karmaşıklaştırdı, işin tek düzeliğini değiştirdi.

Meseleye bu noktada bir ürün, yani donanım veya yazılım meselesi olarak bakmak işi daha da çetrefilli hale getirecektir.

\footnotetext{
* Pareto Yasası: İtalyan ekonomist Vilfredo Pareto tarafindan ortaya konulan (1897) Pareto prensibi, etkilerin \% 80'inin, etkenlerin \% 20'sinden kaynaklandığını öne sürer.
} 
$\mathrm{Bu}$ sebeple meseleye donanım ve yazılım olarak bakmadan, donanım ve yazılıma yatırım yapmadan önce mesleki anlamda hangi kısımların dijital dünyanın gerçekleriyle uyuşup uyuşmadığına, hangi yol ve yöntemlerin bu sistemlerde işleyip hangilerinin işlemediğine bakmak gerekir. Mesleki çerçevede içerik ve eylem olarak nereleri düzeltmeniz ya da daha fazla bilgi edinmek için nereleri durdurmanız, içerik temizliğine gitmeniz veya nerelerde mesleki olarak devreye girilmesi gerekiyor? sorularını cevaplamamı elzemdir.

Dijitalleşmenin iyileşme sağlayabileceği ve mesleğe katkı sağlayacağı olası alanlar bu soruların cevabında yatıyor. Ardından bu alanlardaki faaliyetlerin nasıl tasarlanmış olduğuna bakmak ve teknolojinin süreçleri hızlandırarak, iyileştirerek ve daha kolaylaştırarak nasıl katkı sağlayabileceğini düşünmek, mesleğin kurallarını ve süreçlerini sisteme eklemlendirmek gerekecektir.

Herhangi bir dijital dönüşüm stratejisindeki temel sorulardan bir tanesi de şudur: Mesleğimiz için yeni değer oluşturmak adına dijital mesleki süreçlerimiz neler olmalıdır ve bu çerçevede veriyi ve dijital yetkinlikleri nasıl kullanabiliriz? Çözüm nerededir?

Dijital dönüşümü benimsemek demek zihinsel dönüşüme başlamak demektir. Öncelikle eğitim içeriğimizin, bilgi ve beceri birikimimizin farklı rotalar üzerinden yeniden belirlenip hızla hayata dâhil edilmesi lazımdır. Bunu yaparken mesleğin uygulama sahası olan kurumlardan, özel işletmelere hatta bireysel hizmetlere kadar geniş bir yelpazeye dair bilgi birikiminin, değişik disiplinlere ait bilgilerin, operasyonel bakış açısının ve derinlemesine geliştirilecek, eğitilecek, donatılacak öğrenci ve personel havuzunun oluşturulması şarttır.

\section{Sonuç}

Önümüzdeki dönemler, mesleğimizin ciddi sınavlardan geçmek zorunda olacağı dönemler gibi görünüyor. Dijitalleşme, elektronikleşme, yapay zekâ gibi olguların insanlığa sağladığı yeni imkânlarla beraber getirebileceği zafiyetler, tehlikeler, belge/bilgi yönetiminin tüm bildiklerini ve en önemlisi alışkanlıklarını gözden geçirmesi gerektiğini bizlere söylüyor. Gelecek belirsiz de olsa, geçmişten ve bugünden farklı olarak mesleğin yapısallığında, becerilerinde, bilgi birikiminde ve en önemlisi zihniyetinde köklü değişiklikler olacak gibi duruyor. Bu değişimler bugünkü meslek profesyonellerince değerlendirmeye tabi tutulup önlem alınmazsa başka formasyonlar rol çalarak doğan boşluğu doldurabilecektir. Birçok şeyde olduğu gibi bu konuda da atılacak ilk adım mesleği şekillendiren, içini dolduran, bilgi ve beceri kazandıran eğitim unsurunun içeriği ve modeli üzerinden yürütülmelidir.

Yeni imkânların oluşturduğu, ama aynı zamanda her şeyi katmanlaştırıp sarmal hale getirip çetrefilleştirdiği dünyaya uygun bir eğitim sistemine geçiş yönündeki paradigma değişikliğinin vakti çoktan gelmiştir. Bunun için alışageldiğimiz, rutine binmiş bakış açılarımızı, paradigmalarımızı değiştirmemiz gerekiyor. Dijital dünyayla ilgili gelişmeleri doğru okur, bilgi birikimimizi ve becerilerimizi doğru bir şekilde yönlendirirsek önümüze çıkacak imkânlarla bilgece ve değerlenmiş bir mesleki gelecek inşa edebiliriz.

Elbette mesleki açıdan önümüzdeki yakın ve orta vadedeki gelecekte bizi bekleyenleri yahut bize sunacağı imkânları tam olarak bilemiyor, ama bazı şeyleri yaşadıklarımızla harmanlayarak hissedebiliyoruz. Gelecek senaryolarıyla ilgili çözümlenemeyecek çok şey olmakla birlikte, çözüm yolunda atılacak adımlarla ilgili hiçbir mesele yoktur. Bu doğrultuda farklı düşünme, başka pencereden bakma becerimizi devreye sokarak geç kalmadan yeni dünyaya adapte olabiliriz. Biz bu paradigma değişikliğini yapmasak da, tüm iş süreçlerinin bir şekilde elektronikleşeceği, dijitalleşeceği dönemde meslektaşların bir kısmı son derece rutin dışı, çözüm odaklı eylemlerde bulunacaklardır. Muhtemelen konulara o zamana kadar akla gelmeyen bambaşka açılardan yaklaşan, son derece çarpıcı ve yenilikçi yaklaşımlar üretecekler, aşılması zor denen nice engeli aşacaklar, yapılamaz diye düşünülen nice girişimleri gerçekleştireceklerdir. Ama asli mesele bu az sayılda belge/bilgi yöneticisinin, profesyonelinin yaratacağı, yenilikçi ve gelişmiş iklimin meslek elemanlarının ve adaylarının tamamına erişmesini sağlamaktır.

Dolayısıyla önümüzdeki süreçlerde mesleki olarak etkinliğimizi sağlamak, değerlenmek istiyorsak öncelikle yeni gerçekliklere yönelik içeriklerle eğitim sisteminde paradigma değişikliğine gitmemiz, günün gerçekleriyle örtüşmeyen içeriklerden ve müfredatlardan hızlıca kurtulmamız gerekmektedir. Bunun isabetli bir şekilde yapılabilmesi, doğru bileşenlerin bir araya getirilerek bilinçli ve bilgece bir 
bakış açısıyla değerlendirilip hayata geçirilmesine bağlıdır. Çünkü gelecek her şeyde olduğu gibi mesleki açıdan da belirsizliklerle doludur. Bu makale bu belirsizliklere hazırlıksız yakalanmamak için atılacak ilk adımla ilgili, bir zihin egzersizi olarak kaleme alınmıştır.

Yapmaya çalıştığım şey, mesleki geleceğe yönelik olabilecekler ve bu çerçevede olması gerekenler üzerinden hayal gücümüzü kışkırtmak ve bu makaleyi okuyan meslek profesyonellerinin ve henüz bu konuda eğitim alanların gelecekteki konumlarına, meslek alanlarına yönelik bazı çıkarımlarda bulunmak üzere ipuçları elde etmelerine aracılık etmektir. Elbette gelecek bizim önerilerimizden, tahminlerimizden çok farklı bir güzergâha da evrilebilir. Geleceği bugün yaptıklarımızla biz şekillendirecekmiş gibi düşünsek de aslında onu yeni kuşaklar inşa edecektir. Asli rotayı onlar belirleyecektir. Ancak şunu da unutmayalım, bugünkü yönetici ve lider kuşak olarak bizim sahip olduğumuz öngörülerimiz, kararlarımız, dünyaya bakışımız, algılama biçimimiz ve bu doğrultudaki eylemlerimiz, gençlerimizin altyapısını, niteliklerini ve kalitesini belirleyen en önemli etmen olacaktır.

$\mathrm{Bu}$ yazıda verilmek istenen mesajlar bu çerçevede değerlendirilmelidir. Bize düşen bu yolda onlara farklı bileşenleri ve rutin dışı olanları da göstermek, eğer gerçekten formasyonel bir tehlike varsa kendimize çeki düzen vermek üzere, belirsizliğe karşı bazı erken uyarı noktaları tespit ederek oluşabilecek mesleki güç kaybına, rol kaptırmasına dikkat çekmektir.

\section{Kaynakça}

Canan, S. ve Acungil, M. (2018). Dijital Gelecekte İnsan Kalmak. İstanbul: Tutikitap.

Çağlar, S. (2020). "Pareto Prensibi Nedir?". Erişim adresi: https://www.kigem.com/pareto-prensibinedir.html.

Çağlar, S. (2020). "Pareto Analizi-80/20 Kuralı".

Erişim adresi: https://www.matematiksel.org/pareto-analizi-8020-prensibi/.

Connerton, P. (2019). Toplumlar Nasıl Anımsar? İstanbul: Ayrıntı Yayınları.

Göksel, B. (2020). Sistemi Dönüştürmek İçin Zihin Yapısını Dönüştürmek Gerekli. Erişim adresi: https://hbrturkiye.com/dergi/sistemi-donusturmek-icin-zihin-yapisini-donusturmek-gerekli

İhs teknoloji. (2020), Hiper Bütünleşik Altyapı Çözümleri. Erişim adresi: https://www.ihsteknoloji.com/hiper-butunlesik-altyapi-cozumleri/. 20 Nisan 2020.

Külcü, Ö. (2006). "Üniversitelerde Kalite Uygulamaları ve Belge Yönetimi: Hacettepe Üniversitesi Örneği”, Hacettepe Üniversitesi Edebiyat Fakültesi Dergisi, 23 (1), 205-229.

McLuhan, M. (2014). Gutenberg Galaksisi: Tipografik Insanın Oluşumu. İstanbul: Yapı Kredi Yayınlar1.

Öksüz, İ. (2017). Alt Akıl: Aptallar ve Diktatörler. Ankara: Panama Yayın.

Özdemirci, F. (2017). "Belge ve Arşiv Yönetiminde Yeni Ufuklar ve Kuramsal Yaklaşımlar”. Bilgi ve Belge Yönetimi: Kuramsal Yaklaşımlar içindel Yay. Haz. Bülent Yılmaz, Turgay Baş, Semanur Öztemiz, Meltem Dişli. İstanbul: Hiperlink, 219-232.

Özdemirci, F. ve Aydın, C. (2008). Kurumsal Bilgi Kaynakları ve Bilgi Yönetimi= Institutional Knowledge Sources and Knowledge Management, Türk Kütüphaneciliği, 22 (1), 59-81.

Taleb, N. N. (2019). Siyah Kuğu Olasılıksız Görünenin Etkisi. İstanbul: Varlık Yayınları.

Torunlar, M ve F. Özdemirci. (2014). Bilgi Çă̆ı”nın Arşivcileri: Disiplinlerarası Gezginler, Bilgi Dünyası, 15 (2), 396-420.

Reis, H. T. (2018). Paradigma Değiş̧imi/Kayması. Erişim adresi: http://www.felsefetasi.org/paradigmadegisimi-kaymasi/.

Y1lmaz, M. (2005). “80/20 Kuralı”, Türk Kütüphaneciliği, 19 (3), 1-13. 